\title{
ANALISIS PENGARUH KUALITAS PELAYANAN TERHADAP KEPUASAN PELANGGAN PADA RESTORAN FOOD FESTIVAL DI BANDAR LAMPUNG
}

\author{
Ahiruddin $^{(1)}$, Dennis Regina Oktavicena ${ }^{(2)}$ \\ Fakultas Ekonomi Universitas Sang Bumi Ruwa Jurai \\ ahiruddin@fe.saburai.ac.id,reginadennis.oktavicena@gmail.com
}

\begin{abstract}
Abstrak. Dampak positif dari pelayanan yang baik akan meningkatkan kepuasan dan kesetiaan pelanggan serta keinginan untuk melakukan pembelian kembali (re-buying), yang tentunya akan meningkatkan pendapatan yang diterima dari produk yang telah terjual. Kepuasan pelanggan merupakan suatu perasaan senang atau kecewa seseorang yang muncul setelah membandingkan antara persepsi atau kesannya terhadap kinerja (hasil) suatu produk yang dihasilkan oleh perusahaan. Kualitas pelayanan yang diberikan pegawai restoran food festival kurang memuaskan hal ini terlihat dari data keluhan pelanggan. Tujuan penelitian ini adalah untuk mengetahui seberapa besar pengaruh kualitas pelayanan terhadap kepuasan pelanggan Restoran Food Festival Bandar Lampung. Metode analisis yang di gunakan dalam penelitian ini adalah Analisis kualitatif dan kuantitatif. Responden dalam penelitian ini adalah konsumen di restoran Food Festival yang berjumlah 100 orang responden. Hasil penelitian di peroleh persamaan Regresi Linier Sederhana Y $=5,99+$ $0,886 \mathrm{X}$. Nilai signifikan $(4,673>1,661)$ dari hasil tersebut, maka kualitas pelayanan $(\mathrm{X})$ berpengaruh terhadap kepuasan pelanggan (Y) pada Restoran Food Festival di Bandar Lampung.
\end{abstract}

Kata kunci: Kepuasan, Kualitas, Pelanggan, Pelayanan.

\section{PENDAHULUAN}

Perkembangan bisnis sangat pesat dan mengalami metamorfosis yang berkesinambungan. Dimana salah satu contoh perubahan tersebut yaitu dalam hal perubahan teknologi dan gaya hidup, dimana hal ini tak lepas dari pengaruh globalisasi yang kini terjadi. Dalam era globalisasi ini, jumlah produk yang bersaing dalam pasar menjadi sangat banyak sehingga konsumen memiliki ragam pilihan dan alternatif produk dan jasa yang dapat memenuhi kebutuhannya dan berhak memilih sesuai yang konsumen inginkan. Dengan adanya persaingan yang terjadi, hal tersebut menuntut para pelaku bisnis untuk mengeluarkan segala kemampuan yang mereka miliki agar dapat bersaing di pasar.

Perkembangan perdagangan pada era globalisasi ini tidak dapat dipungkiri tidak luput dari persaingan yang semakin ketat dalam memasarkan produk dan jasa.
Sehingga setiap perusahaan dituntut untuk selalu berusaha keras dalam berinovasi agar mampu bertahan dari persaingan dan mampu menarik perhatian dari calon konsumen akan produk yang ia tawarkan. Namun hal yang perlu diperhatikan sebelum merancang inovasi, seseorang harus jelas terlebih dahulu segmentasi dan target mana yang akan disasar. Selain tiap perusahaan dituntut untuk lebih berinovasi.

Tujuan pemasaran sendiri menurut seorang pakar teori manajemen terbuka Peter Drucker (2012), tujuan pemasaran adalah mengetahui dan memahami pelanggan dan selanjutnya mampu menjual dirinya sendiri. idealnya, pemasaran harus memaksimalkan pelanggan yang siap membeli. yang dibutuhkan selanjutnya adalah menyediakan produk atau jasa itu (Kotler 2013).

Pelayanan adalah total persepsi terhadap objek yang dibentuk dengan memproses informasi dari berbagai sumber 
setiap waktu. (Nugroho J. Setiadi, 2013). Pelayanan yang buruk menimbulkan persepsi produk tidak berkualitas, sehingga pelanggan mudah marah untuk setiap kesalahan kecil sekalipun karena kebutuhan dan keinginannya tidak terpenuhi sehingga pelanggan akan merasa tidak puas dan berpindah ke perusahaan lainnya. Pelayanan yang baik menimbulkan persepsi produk berkualitas, sehingga pelanggan memaafkan suatu kesalahan, meskipun tidak untuk kesalahan selanjutnya dan kebutuhan serta keinginannya terpenuhi sehingga pelanggan pun akan merasa puas dan loyal terhadap perusahaan tersebut.

Dampak positif dari pelayanan yang baik akan meningkatkan kepuasan dan kesetiaan pelanggan serta keinginan untuk melakukan pembelian kembali (re-buying), yang tentunya akan meningkatkan pendapatan yang diterima dari produk yang telah terjual. Agar dapat bersaing, bertahan hidup, dan berkembang, maka perusahaan dituntut untuk mampu memenuhi kebutuhan dan keinginan pelanggan dengan memberikan pelayanan yang terbaik dan berkualitas, maka dengan begitu pelanggan akan merasa mendapat kepuasan tersendiri dan merasa dihargai sehingga mereka senang dan bersedia untuk menjadi pelanggan tetap.

Salah satu bidang bisnis yang juga merasakan ketatnya persaingan saat ini adalah bisnis di bidang Restoran Food Festival menjadi salah satu tempat makan favorit di Bandar Lampung. Menu makanan yang komplet dan higienis menjadi ciri khas tersendiri. Suasana yang nyaman dan bersih juga melekat di restoran ini. Untuk melengkapi pelayanan kepada konsumen, restoran food festival yang berlokasi di Jln. Gatot Subroto Garuntang Bandar Lampung kini dilengkapi ruang pertemuan atau meeting room dengan kapasitas 50 orang. Selain itu, tersedia juga function room untuk 100 orang , 300 orang ,dan 500 orang. Fasilitas ini cocok untuk pertemuan (meeting) perusahaan, convention, acara ulang tahun, arisan, pernikahan, gathering, hingga launching produk. Bahkan ada live music setiap Sabtu dan Minggu.

Untuk diketahui, Food Festival terdiri tiga lantai dengan menu masakan berbeda. Di lantai satu tersedia blueberry bread dan donat. Ada sekitar 41 aneka roti dan donat lezat tersaji lengkap di sana. Ada juga yammie babat yang menyajikan aneka bakmi dan batagor. Lalu, di lantai II tersedia pilihan menu makan siang dan malam selain itu pengunjung dapat menikmati aneka makanan khas sunda . Menariknya, pengunjung dipersilakan mengambil sendiri menu yang tersedia. Menu yang ditawarkan, antara lain, ayam bakar dan goreng, daging, pepes tahu, pepes peda, tempe, serta aneka ikan goreng.

Sementara di lantai III, konsumen ditawarkan suasana yang lebih formal.Bagi yang ingin menjamu relasi sambil berkaraoke Green Papper, lantai tiga dapat dijadikan rujukan.Di sini terdapat aneka masakan populer dari Malaysia, Jepang, dan makanan Barat. Restoran Food Festival menggunakan konsep open kitchen (dapur terbuka), sehingga semua aktivitas memasak para koki dan chef dapat dilihat pengunjung.

Masih banyak terdapat keluhankeluhan pelanggan pada Restoran Food Festival. Dengan meminimalisir macammacam keluhan di atas menjadi pekerjaan penting bagi manajemen agar kepuasan konsumen dapat ditingkatkan.Maka disini pihak manajemen dituntut untuk bisa memberi keyakinan kepada masyarakat atau pelanggan Restoran Food Festival agar bisa kembali melakukan pembelian di restoran tersebut. Berdasarkan hal tersebut, maka penulis bermaksud meneliti secara lebih mendalam mengenai: "Analisis Pengaruh Kualitas Pelayanan Terhadap Kepuasan Pelanggan Pada Restoran Food Festival di Bandar Lampung". 


\section{KAJIAN TEORI}

\section{Pengertian Pemasaran}

Kegiatan bisnis selalu ada kompetisi, perusahaan akan terus mencari pasar dan tidak akan pernah puas dengan pasar yang telah di dapatnya. Aktivitas pemasaran diarahkan untuk menciptakan perputaran yang memungkinkan perusahaan dalam mempertahankan kelangsungan hidup. Dalam hal ini, pemasaran memegang peranan penting dalam menentukan sukses atau tidaknya suatu bisnis. Untuk itu, perusahaan harus dapat memahami benar pemasaran bagi perusahaan yang ingin tetap bertahan. Di bawah ini terdapat beberapa pengertian pemasaran menurut para ahli.

Pemasaran adalah proses sosial yang didalamnya individu dan kelompok mendapatkan apa yang mereka butuhkan dan inginkan dengan menciptakan, menawarkan dan secara bebas mempertukarkan produk yang bernilai dengan pihak lain (Kotler 2010). Sedangkan Boyd, Walker dan Larreche (2000) menyatakan, pemasaran adalah suatu proses sosial yang melibatkan kegiatan-kegiatan penting yang memungkinkan individu dan perusahaan mendapatkan apa yang mereka butuhkan dan inginkan melalui pertukaran dengan pihak lain dan untuk mengembangkan hubungan pertukaran.

Berdasarkan definisi-definisi tersebut, dapat disimpulkan bahwa pemasaran merupakan suatu kegiatan manusia untuk memenuhi kebutuhan dan keinginan melalui proses penciptaan, penawaran dan pertukaran (nilai) produk dengan yang lain, dimana dalam pemasaran ini kegiatan bisnis dirancang untuk mendistribusikan barangbarang dari produsen kepada konsumen untuk mencapai sasaran serta tujuan organisasi.

\section{Pengertian Manajemen Pemasaran}

Menurut Kotler dan Keller (2010)yang diterjemahkan oleh Benyamin Molan mendefinisikan manajemen pemasaran sebagai berikut : "Manajemen pemasaran sebagai seni dan ilmu memilih pasar sasaran dan mendapatkan, menjaga, dan menumbuhkan pelanggan dengan menciptakan, menyerahkan, dan mengomunikasikan nilai pelanggan yang unggul". Menurut ini, dapat dikatakan bahwa manajemen pemasaran merupakan suatu proses yang dimulai dari proses perencanaan, pengarahan, dan pengendalian produk atau jasa, penetapan harga, distribusi, dan promosinya dengan tujuan membantu organisasi dalam mencapai sasarannya.

\section{Konsep Pemasaran}

Konsep pemasaran adalah sebuah filsafat bisnis yang mengatakan bahwa kepuasan keinginan dari konsumen adalah dasar kebenaran sosial dan ekonomi kehidupan sebuah perusahaan. Sudah sewajarnya jika segala kegiatan perusahaan harus dicurahkan untuk mengetahui apa yang diinginkan oleh konsumen dan kemudian memuaskan keinginan-keinginan itu. Sudah tentu pada akhirnya perusahaan bertujuan untuk memperoleh laba. Pengertian lain dari konsep pemasaran adalah filsafat manajemen pemasaran untuk mencapai tujuan organisasi tergantung pada penentuan kebutuhan dan keinginan pasar sasaran dan memuaskan pelanggan secara lebih efektif dan efisien daripada yang dilakukan pesaing (Kotler dan Armstrong, 2011).

\section{Tujuan Pemasaran}

Peter Drucker, seorang ahli teori manajemen terkemuka yang diterjemahkan oleh Buchari Alma (2010), mengatakan 
sebagai berikut: "Tujuan pemasaran adalah mengetahui dan memahami pelanggan sedemikian rupa sehingga produk atau jasa itu cocok dengan pelanggan dan selanjutnya menjual dirinya sendiri. Idealnya, pemasaran hendaknya menghasilkan seorang pelanggan yang siap untuk membeli. Semua yang dibutuhkan selanjutnya adalah menyediakan produk atau jasa itu.Dari pendapat diatas dapat ditarik kesimpulan bahwa kegiatan pemasaran bukan sekedar menjual barang yang telah dihasilkan tetapi, kegiatan pemasaran mempunyai tujuan yang lebih penting yaitu memberikan kepuasan terhadap kegiatan dan kebutuhan konsumen.

\section{Kualitas Pelayanan}

Kualitas pelayanan adalah tingkat keunggulan yang diharapkan dan pengendalian atas tingkat keunggulan tersebut untuk memenuhi keinginan pelanggan (Tjiptono, 2005). Ada dua faktor utama yang mempengaruhi kualitas pelayanan perusahaan yaitu harapan pelanggan (expectation) dan kinerja perusahaan yang dirasakan konsumen (performance). Kualitas pelayanan jasa perusahaan dianggap baik dan memuaskan jika jasa perusahaan yang diterima melampaui harapan konsumen, jika jasa perusahaan yang diterima lebih rendah dari pada yang diharapkan maka kualitas pelayanan jasa perusahaan dipersepsikan buruk.

\section{Kepuasan Pelanggan}

Tujuan dari suatu bisnis adalah untuk menciptakan para pelanggan yang merasa puas. Kepuasan pelanggan berkontribusi pada sejumlah aspek krusial, seperti terciptanya loyalitas pelanggan, meningkatnya reputasi perusahaan, berkurangnya elastisitas harga, berkurangnya biaya transaksi masa depan, dan meningkatnya efisiensi dan produktivitas karyawan. Kepuasan Pelanggan adalah adalah perasaan senang atau kecewa seseorang yang berasal dari perbandingan antara kesannya terhadap kinerja (hasil) sesuatu produk dengan harapannya Kotler (2005). Indikator empiris yang digunakan untuk menjelaskan variabel kepuasan pelanggan adalah :

- Tidak ada komplain atau keluhan

- Pemberian pujian dari konsumen

- Memiliki reputasi yang baik

\section{METODE PENELITIAN}

\section{Objek Penelitian}

Objek penelitian ini adalah pelanggan Restoran Food Festival di Bandar Lampung, yang beralamat di Jalan Gatot Subroto No. 159 Garuntang Bandar Lampung. Penelitian ini di laksanakan pada bulan Maret 2016.

\section{Metode dan Teknik Pengumpulan Data}

Dalam penelitian ini jenis data yang diperlakukan adalah :

\section{a. Data Primer}

Data primer merupakan data dasar yang akan diperoleh langsung tanpa perantara orang atau lembaga lain sebagai pihak ketiga. Data primer ini diperoleh dengan wawancara melalui responden dengan menggunakan daftar pertanyaan.

b. Data Sekunder

Data skunder merupakan data yang diperoleh melalui orang lain yang berhubungan dengan permasalahan yang dipecahkan. Data sekunder ini diperoleh melalui cara studi dokumenter yaitu mengumpulkan dan mempelajari brosurbrosur serta dokumen organisasi. 


\section{Sampel dan Populasi}

Sampel didefinisikan sebagai bagian dari populasi yang merupakan wakil-wakil yang representatif dari suatu populasi tersebut (Arikunto, 2010). Penulis mengutif pendapat Suharsimi Arikunto yang menyatakan bahwa : "Apabila dalam suatu penelitian terhadap subjek yang kurang dari 100, maka di ambil semuanya sedangkan apabila subjek lebih dari 100 maka sampel yang diambil antara $10 \%-15 \%$ atau 20 $\%, 25 \%$ atau lebih, dari seluruh populasi yang ada" (Arikunto, 2010). Dalam penelitian ini peneliti mengambil sampel pada saat akhir pekan selama 3 hari dengan mengambil sampel sebanyak 100 orang pelanggan yang dijadikan responden.

\section{Metode Analisis Data}

Untuk pengolahan data dalam bentuk tabulasi hasil jawaban responden kemudian dilakukan analisis data melalui metode analisis secara kualitatif dan analisis kuantitatif.

Analisis kualitatif merupakan analisis yang dinyatakan dalam bentuk uraian dan didasarkan pada data yang telah ada. Analisis kuantitatif yang dilakukan berdasarkan data primer yang diperoleh dari penyebaran instrument (daftar pertanyaan) kepada sampel, dan untuk mengetahui pengaruh dari variabel bebas (independent variable) terhadap variabel terikat (dependent variable).

Persamaan Regresi Linear Sederhana menentukan persamaan regresi linear sederhana untuk $\mathrm{X}$ :

$$
Y=a+b X+e
$$

Keterangan:

$$
\begin{aligned}
& \mathrm{Y}=\text { Kepuasan pelanggan } \\
& \mathrm{a}=\text { Konstanta } \\
& \mathrm{b}=\text { Koefisien regresi } \mathrm{X} \\
& \mathrm{X}=\text { Kualitas Pelayanan }
\end{aligned}
$$

$$
\text { e }=\text { Faktor kesalahan }
$$

Untuk mengetahui besarnya pengaruh, penghitungan koefisien korelasi tersebut kemudian dilanjutkan dengan Rumus Koefisien Determinasi atau Koefisien Penentu (KP):

$$
K P=(r)^{2} x 100 \%
$$

Untuk menguji secara hipotesis secara parsial digunakan Uji t dengan rumus :

$$
t_{\text {hitung }}=\frac{r \sqrt{N-2}}{\sqrt{1-r^{2}}}
$$

Keterangan:

$$
\begin{array}{ll}
\mathrm{t}_{\text {hitung }} & =\text { Nilai } \mathrm{t} \\
\mathrm{r} & =\text { Koefisien Korelasi } \\
\mathrm{N} & =\text { Jumlah responden }
\end{array}
$$

Kriteria untuk Uji $\mathrm{t}$ adalah sebagai berikut :

a) Jika $t_{\text {hitung }}>t_{\text {tabel }}$ maka Ha diterima dan Ho ditolak.

b) Jika $t_{\text {hitung }} \leq \mathrm{t}_{\text {tabel }}$ maka Ha ditolak dan Ho diterima.

Taraf signifikan dalam penelitian ini digunakan $\alpha=0,05$ atau 5\%. Yang dimaksud dengan Hipotesis nol (Ho) dan Hipotesis alternatif (Ha) adalah :

Ho $=\mathrm{r} \leq 0=$ Berarti tidak ada pengaruh kualitas pelayanan terhadap kepuasan pelanggan

$\mathrm{Ha}=\mathrm{r}>0=$ Berarti ada pengaruh kualitas pelayanan terhadap kepuasan pelanggan.

\section{HASIL DAN PEMBAHASAN}

Data penelitian yang telah dikumpulkan kemudian diolah untuk menguji kualitas data berupa uji validitas dan reliabilitas menunjukkan bahwa koefisien korelasi pearson moment untuk setiap item butir pertanyaan dengan skor 
total variabel kualitas pelayanan $(\mathrm{X})$, dan kepuasan pelanggan $(\mathrm{Y})$ signifikan pada tingkat signifikan $\alpha 0,05$. Dengan demikian dapat diinterprestasikan bahwa setiap item indikator instrumen masing-masing variabel tersebut valid.

\section{Uji Validitas}

Uji validitas digunakan untuk menguji sejauh mana ketepatan alat pengukur dapat mengungkapkan konsep gejala/kejadian yang diukur. Pengujian validitas dilakukan dengan menggunakan rumus korelasi. Pengujian validitas selengkapnya dapat dilihat pada Tabel 1.

\begin{tabular}{|c|c|c|c|c|}
\hline No & Indikator & rhitung & Itabel & Keterangan \\
\hline 1 & $\begin{array}{c}\text { Rualitas Pelayanan } \\
\text { - Indikator } 1 \\
\text { - Indikator } 2 \\
\text { - Indikator } 3 \\
\text { - Indikator } 4 \\
\text { - Indikator } 5 \\
\text { - Indikator } 6 \\
\text { - Indikator } 7 \\
\text { - Indikator } 8 \\
\text { - Indikator } 9 \\
\text { - Indikator } 10\end{array}$ & $\begin{array}{l}0,734 \\
0,770 \\
0,685 \\
0,629 \\
0,652 \\
0,630 \\
0,683 \\
0,793 \\
0,712 \\
0,712\end{array}$ & $\begin{array}{l}0,196 \\
0,196 \\
0,196 \\
0,196 \\
0,196 \\
0,196 \\
0,196 \\
0,196 \\
0,196 \\
0,196\end{array}$ & $\begin{array}{l}\text { Valid } \\
\text { Valid } \\
\text { Valid } \\
\text { Valid } \\
\text { Valid } \\
\text { Valid } \\
\text { Valid } \\
\text { Valid } \\
\text { Valid } \\
\text { Valid }\end{array}$ \\
\hline 2 & $\begin{array}{rr}\text { Repuasan Pelanggan } \\
\text { - } & \text { Indikator } 1 \\
\text { - } & \text { Indikator } 2 \\
\text { - } & \text { Indikator } 3 \\
\text { - } & \text { Indikator } 4 \\
\text { - } & \text { Indikator } 5 \\
\text { - Indikator } 6 \\
\text { - Indikator } 7 \\
\text { - Indikator } 8 \\
\text { - Indikator } 9 \\
\text { - Indikator } 10\end{array}$ & $\begin{array}{l}0,654 \\
0,732 \\
0,699 \\
0,722 \\
0,688 \\
0,611 \\
0,709 \\
0,789 \\
0,691 \\
0,672\end{array}$ & $\begin{array}{l}0,196 \\
0,196 \\
0,196 \\
0,196 \\
0,196 \\
0,196 \\
0,196 \\
0,196 \\
0,196 \\
0,196\end{array}$ & $\begin{array}{l}\text { Valid } \\
\text { Valid } \\
\text { Valid } \\
\text { Valid } \\
\text { Valid } \\
\text { Valid } \\
\text { Valid } \\
\text { Valid } \\
\text { Valid } \\
\text { Valid }\end{array}$ \\
\hline
\end{tabular}

Tabel 1. menunjukkan bahwa semua indikator yang digunakan untuk mengukur variabel-variabel yang digunakan dalam hasil penelitian ini mempunyai $r$ hitung yang lebih besar dari $r$ table untuk sampel sebanyak 100 orang yaitu 0,196. Nilai $r$ hitung disajikan pada Tabel 7 Dari hasil tersebut menunjukkan bahwa semua indikator variabel kualitas pelayanan dan kepuasan pelanggan adalah valid.

\section{Uji Reliabilitas Data}

Pengujian reliabilitas dalam penelitian ini adalah dengan menggunakan rumus Alpha. Hasil pengujian reliabilitas untuk masing-masing variabel yang diringkas pada Tabel 2 .

Tabel 2. Hasil Pengujian Reliabilitas

\begin{tabular}{lcl}
\hline \multicolumn{1}{c}{ Variabel } & Alpha & Keterangan \\
\hline Kualitas Pelayanan & 0,884 & Reliabel \\
Harga & 0,961 & Reliabel \\
Promosi & 0,746 & Reliabel \\
Kepuasan Pelanggan & 0,881 & Reliabel
\end{tabular}

Hasil uji reliabilitas pada Tabel 2 . menunjukkan bahwa semua variabel mempunyai koefisien Alpha yang cukup besar yaitu diatas 0,60 sehingga dapat dikatakan semua konsep pengukur masingmasing variabel dari kuesioner adalah reliabel sehingga untuk selanjutnya itemitem pada masing-masing konsep variabel sebagai alat ukur.

\section{Analisis Kuantitatif}

Berdasarkan hasil perhitungan diperoleh persamaan regresi linear sederhana yaitu $\mathrm{Y}=5,99+0,886 \mathrm{X}$. Nilai koefesien regresi untuk variabel kualitas kompetensi (X) sebesar 0,886 mengandung arti bahwa terdapat pengaruh positif antara variabel Kualitas pelayanan (X) terhadap variabel Kepuasan pelanggan (Y) pada Restoran Food Festival di Bandar 
Lampung, sehingga setiap peningkatan yang dilakukan terhadap variabel Kualitas Pelayanan (X) maka akan meningkatkan variabel Kepuasan Pelanggan (Y) pada Restoran Food Festival di Bandar Lampung 0,886 .

Koefisien determinan $\left(\mathrm{R}^{2}\right)$ digunakan untuk mengetahui kontribusi variabel bebas dalam menjelaskan variabel terikat. Semakin besar nilai koefisien determinasi maka menunjukkan semakin besar pula pengaruh variabel terikat terhadap variabel bebas. Hasil perhitungan $R$ Square $\left(R^{2}\right)$ sebesar 0,535 atau $53,5 \%$ artinya bahwa variabel $\mathrm{X}$ mempunyai kontribusi terhadap variabel $\mathrm{Y}$ sebesar 53,5\% sedangkan sisanya mempunyai kontribusi dengan variabel lain yang tidak diteliti di penelitian ini.

Untuk menguji keberartian model regresi untuk masing-masing variabel dapat diperoleh dengan menggunakan uji t. Nilai signifikan adalah 4,673>1,661 dari hasil tersebut keputusannya yang dapat di ambil yaitu menolak Ho dan menerima Ha, maka Kualitas Pelayanan (X) berpengaruh terhadap Kepuasan Pelanggan (Y) pada Restoran Food Festival di Bandar Lampung.

Hasil penelitian menunjukkan bahwa variabel kualitas layanan memiliki pengaruh yang positif dan signifikan terhadap kepuasan pelanggan. Hasil ini memberikan bukti empiris bahwa kualitas layanan yang diberikan oleh Restoran Food Festival meliputi tempat parkir yang luas dan bangunan menarik, ruang makan menarik, pelayanan tepat waktu, pelayanan memberikan sesuai dengan pesanan, pelayanannya yang cepat, melayani pada jam-jam sibuk, pegawai yang berpengalaman, mampu menjawab pertanyaan dengan baik, pegawai yang simpatik, pegawai yang memperhatikan kebutuhan dan keinginan pelanggan dapat mempengaruhi Kepuasan pelanggan.

\section{KESIMPULAN DAN SARAN}

\section{Kesimpulan}

Dari hasil analisis data dan pembahasan dapat disimpulkan bahwa kualitas pelayanan berpengaruh positif terhadap kepuasan pelanggan pada Restoran Food Festival di Bandar Lampung. Hal ini dibuktikan dari hasil persamaan regresi linear dimana nilai koofesien regresi variabel kompetensi kerja adalah sebesar 0,886 $\mathrm{X}$ dan juga hasil uji hipotesis, yakni uji $t$, dimana nilai thitung pada $\alpha=0,05$ sebesar 4,673 sehingga nilai $t_{\text {hitung }}>t_{\text {tabel }}$. Dengan demikian bahwa Kualitas Pelayanan berpengaruh positif terhadap Kepuasan Pelanggan Restoran Food Festival di Bandar Lampung terbukti dan dapat diterima kebenarannya.

\section{Saran}

Adapun saran yang diajukan peneliti adalah Restoran Food Festival perlu memperhatikan kualitas pelayanan. Usaha yang dapat dilakukan adalah memperluas lahan parkir karena itu merupakan faktor yang cukup penting agar dapat membuat para konsumen nyaman karena dilihat dari para konsumen yang datang tidak sebanding dengan jumlah kendaraan yang diparkir. Usaha lain yang dapat dilakukan adalah menambah interior agar bangunan dan ruangan yang dimiliki lebih menarik dan membuat nyaman konsumen Restoran Food Festival.

\section{DAFTAR PUSTAKA}

Bernadine. 2005. Analisis Pengaruh Kualitas Layanan terhadap Kepuasan Pelanggan Studi Kasus pada Rumah Makan Pondok Laras di Kelapa Dua Depok. Jurnal Ekonomi Perusahaan. Vol. 12, No. 03. Pp. 318-336. 
Fandy Tjiptono. 2005. Pemasaran Jasa, Edisi pertama. Malang: Bayu Media Publishing.

Ghozali, Imam. 2009. Aplikasi Analisis Multivariate dengan Program SPSS. Semarang: Badan Penerbit Universitas Diponegoro.

Hadi, Sutrisno. 2005. Metodologi Research. Yogyakarta: Penerbit Andi.

Hasan, Mustafa. 2000. Teknik Sampling. Jakarta: Erlangga.

Kotler, Philip dan A.B Susanto. 2000. Manajemen Pemasaran Jasa Indonesia, Analisis Perencanaan, Implementasi dan pengendalian (Edisi pertama). Jakarta: Salemba Empat.

Kotler, Philip. 2006. Manajemen Pemasaran (Edisi Milenium). Jakarta: PT

Prenhalindo.

Kotler, Philip. 2009. Manajemen Pemasaran. Jakarta : Erlangga.

Lupiyoadi, Rambat. 2008. Manajemen Pemasaran Jasa - Teori dan Praktek. Jakarta: Salemba Empat.

Rambat Lupiyoadi. 2004. Manajemen Pemasaran Jasa : Teori dan Praktek. Jakarta: PT. salemba Empat.

Setiadi, Nugroho J. 2003. Perilaku Konsumen: Konsep dan Implikasi untuk strategi dan Penelitian Pemasaran. Jakarta: Prenada Media.

Sugiyono. 2007. Statistika Untuk Penelitian. Bandung: Alfabeta.

Sugiyono. 2009. Metode Penelitian Bisnis. Bandung: CV. Alfabeta.
Sulaiman, Wahid. 2002. SPSS 10 Jalan Pintas Menguasai. Yogyakarta: Penerbit Andi.

Tjiptono, Fandy. 2007. Strategi Pemasaran, Edisi 2. Yogyakarta: Penerbit Andi. 